\title{
PEMANFAATAN LIMBAH JAGUNG UNTUK PEMBUATAN BISKUIT PAKAN HIJAUAN DI KECAMATAN LIMA KAUM BATUSANGKAR
}

\author{
Maya Sari \\ Jurusan Tadris Kimia Fakultas Tarbiyah dan Ilmu Keguruan IAIN Batusangkar. \\ Jalan Sudirman No. 137 Kubu Rajo Lima Kaum Batusangkar \\ Email:mayasari_1985@yahoo.com
}

\begin{abstract}
Biscuits Feed Forage is obtained by the technique Silage. These biscuits can be made from agricultural waste including corn waste. As one of the agricultural centers in West Sumatra, corn production in the District Batusangkar very high. However, agricultural production is not followed by the management of agricultural waste are mostly just burned. The purpose of the study was to test to make biscuits forage from corn waste using techniques silage accompanied with the addition of nutrients, the test mold making biscuits conventionally made using the technique of pressure, conducting organoleptic test and analysis proximate to product biscuit feed forage already made. The results were obtained from waste animal feed forage of good quality corn silage by using the technique. treatment P2 (corn leaves $1 \mathrm{~kg}+5 \%+$ molasses urea 10\%) and T1 (1minggu after harvest). Green feed made with the best formula is packaged in the form of biscuits using conventional printing equipment.
\end{abstract}

Keywords: feed, corn straw, silage

\section{PENDAHULUAN}

Batusangkar yang mempunyai luas wilayah $1336 \mathrm{~km}^{2}$ merupakan salah satu lumbung jagung di Kabupaten Sumatera Barat. Dari total seluruh wilayah tersebut hampir $80 \%$ nya merupakan lahan pertanian. Produksi jagung setiap tahunnya selalu mengalami kenaikan. Berdasarkan data BPS Tanah Datar diperoleh informasi bahwa pada tahun 2013 produksi jagung di Tanah Datar adalah 18,51 juta ton dan pada tahun 2014 adalah 19,13 juta ton. Kenaikan produksi ini memperlihatkan upaya pemerintah dalam mewujudkan revitalisasi pertanian di Indonesia. Data ini sekaligus memperkuat limbah jagung yang dapat dimanfaatkan sebagai pakan ternak.

Pemanfaatan limbah pertanian memang menjadi salah satu upaya mengatasi rendahnya kuantitas ransum. Limbah pertanian seperti daun jagung dapat dimanfaatkan sebagai pakai ternak karena mempunyai zat aktif yang dapat memacu produktivitas ternak. Akan tetapi, pada musim kemarau terjadi penurunan energi, mineral, maupun protein yang terkandung dalam pakan hijauan. Hal ini terjadi karena tanaman hijauan mengalami defisit air selama pertumbuhannya. Selain itu, ketersediaan pakan hijauan selama musim ini juga berkurang sehingga terjadi penurunan pertumbuhan ternak. Untuk menyiasati hal tersebut diperlukan perlakuan khusus terhadap pakan hijauan.

Silase merupakan salah satu contoh dari pakan hijauan yang memperoleh perlakuan khusus. Silase adalah pakan dari limbah pertanian atau dari hijauan makanan ternak yang diawetkan dengan cara fermentasi anaerob dalam kondisi kadar air tinggi (40-80\%) sehingga hasilnya bisa disimpan tanpa merusak 
zat makanan/gizi di dalamnya. Maksud pembuatan silase adalah pengawetan hijauan makanan ternak dengan memperhatikan kehilangan nutisi yang minimal dan menghindarkan dari perubahan komposisi kimianya. Kualitas yang baik diperlihatkan melalui beberapa parameter seperti $\mathrm{pH}$, asarn laktat, warna, tekstur, suhu, persentase kerusakan dan kandungan nutisi dari silase (Ridwan dkk., 2005).

Prinsip pembuatan silase adalah fermentasi hijauan oleh mikroba yang banyak menghasilkan asam laktat. Fermentasi merupakan proses perombakan dari struktur keras secara fisik, kimia, dan biologis sehingga bahan dari struktur kompleks menjadi sederhana sehingga daya cerna ternak menjadi lebih efisien (Hanafi, 2008). Fermentasi merupakan proses pemecahan senyawa organik menjadi sederhana yang melibatkan mikroorganisme. Proses fermentasi dapat meningkatkan ketersediaan zat-zat makanan seperti protein dan energi metabolis serta mampu memecah komponen kompleks menjadi komponen sederhana (Zakariah., 2012). Lebih lanjut Yuanita (2012) menyatakan bahwa Fermentasi merupakan proses pemecahan karbohidrat dan asam amino secara anerobik, yaitu tanpa memerlukan oksigen. Senyawa yang dapat dipecah dalam proses fermentasi terutama karbohidrat, sedangkan asam amino hanya dapat difermentasi oleh beberapa jenis bakteri tertentu. Fermentasi sebagai suatu proses dimana komponen komponen kimiawi dihasilkan sebagai akibat adanya pertumbuhan maupun metabolisme mikroba. fermentasi dapat meningkatkan nilai gizi bahan berkualitas rendah serta berfungsi dalam pengawetan bahan pakan dan merupakan suatu cara untuk menghilangkan zat anti nutrisi atau racun yang terkandung dalam suatu bahan pakan.

Agar silase yang dibuat menjadi lebih padat, kompak dan remah, maka silase dibuat dalam bentuk biskuit. Biskuit suplemen pakan ini dibuat dengan menggunakan bantuan panas dan tekanan. Keuntungan dari biskuit silase ini adalah tahan lama (9 minggu), tersedia sepanjang waktu ,aman bagi kesehatan ternak, mudah dan murah. Tujuan dari penelitian adalah untuk mendapatkan produk pakan berkualitas tinggi yang tersedia sepanjang musim dengan memanfaatkan limbah pertanian.

\section{METODE PENELITIAN}

\section{Alat dan Bahan}

Adapun bahan yang digunakan adalah jerami jagung, kalsium karbonat, urea, molases dan bahan untuk analisis proksimat. Peralatan yang digunakan adalah polybag, tali rapiah, gunting dan seperangkat peralatan laboratorium untuk analisis proksimat.

\section{Prosedur Penelitian}

Tahap pertama jerami jagung dilayukan selama $2-3$ jam hingga mencapai kadar air \pm $60 \%$. Selanjutnya dicincang $\pm 3 \mathrm{~cm}$ kemudian ditambahkan Urea 5\%, Molases 10\% dan Kalsium Karbonat $0,5 \%$ sesuai dengan perlakuan (P0, P1, P2 dan P3). Selanjutnya diaduk rata dan difermentasikan di dalam polybag dengan kondisi anaerob dan disimpan di tempat teduh selama 21 hari. Setelah 21 hari, dilakukan penilaian organoleptik meliputi: warna, aroma, tekstur dan ada tidaknya jamur. Tahap ke-2 sampel di ambil pada setiap perlakuan dan masing - masing sampel ditimbang kemudian dilakukan analisis proksimat (AOAC, 1990).

Penelitian dirancang menggunakan Rancangan Acak Lengkap (RAL) yang terdiri dari 4 perlakuan dan 3 ulangan. Komposisi perlakuan sebagai berikut: P0 : Daun jagung $1 \mathrm{~kg}$ (kontrol), P1 : Daun jagung $1 \mathrm{~kg}+$ Urea 5\%, $\mathrm{P} 2$ : Daun jagung $1 \mathrm{~kg}+$ Urea $5 \%+$ Molases 10 $\%$, P3 : Daun jagung $1 \mathrm{~kg}+$ Urea $5 \%+$ Molases $10 \%+\mathrm{CaCO}_{3} 0,5 \%$

\section{Pengukuran Parameter}

Untuk mengetahui Kandungan bahan kering dilakukan langkah sebagai berikut; Cawan porselin yang bersih dimasukkan ke dalam oven dan pada suhu $105^{\circ} \mathrm{C}$ selama 24 jam kemudian didinginkan kedalam desikator selama 30 menit dan ditimbang (a gram). Sampel sebanyak \pm 1 gram dimasukkan ke dalam cawan porselin dan ditimbang bersamasama (b gram). Kemudian dikeringkan dalam oven pada suhu $105^{\circ} \mathrm{C}$ selama 24 jam dan 
setelah kering didinginkan dalam desikator dan ditimbang kembali (c gram).

Pengukuran bahan organik dapat dilakukan sebagai berikut; Sampel dari analisa bahan kering dimasukkan kedalam tanur listrik selama 3 jam pada suhu $600^{\circ} \mathrm{C}$. Tanur dimatikan dan dibiarkan agak dingin kemudian tanur dibuka lalu sampel diambil dan dimasukkan kedalam desikator selama 30 menit, kemudian ditimbang (d gram).

Pengukuran protein kasar dapat dilakukan sebagai berikut; Menimbang sampel \pm 0,5 gram, Masukkan kedalam labu khjedal $100 \mathrm{ml}$, Tambahkan \pm 1 gram campuran selenium dan $10 \mathrm{ml} \mathrm{H}_{2} \mathrm{SO} 4$ pekat (teknis), Labu khjedal bersama isinya digoyangkan sampai semua sampel terbasahi dengan $\mathrm{H}_{2} \mathrm{SO}_{4}$, Destruksi dalam lemari asam sampai jernih , Setelah dingin, tuang dalam labu ukur $100 \mathrm{ml}$ dan dibilas dengan air suling, Tambahkan air suling sampai pada tanda garis , Pipet sampai $10 \mathrm{ml}$ ke dalam labu destilasi dan ditambah dengan $5 \mathrm{ml}$ larutan $\mathrm{NaOH} 30 \%$ dan air suling, Siapkan labu penanmpung yang terdiri dari 10 $\mathrm{ml} \mathrm{H}_{3} \mathrm{BO}_{3} \quad 2 \%$ ditambah dengan 4 tetes indikator campuran dalam erlenmeyer $100 \mathrm{ml}$, Suling hingga volume penampung menjadi 50 $\mathrm{ml}$, Bilas ujung penyuling dengan air suling kemudian penampung bersama isinya dititrasi dengan larutan $\mathrm{H}_{2} \mathrm{SO}_{4} 0,022 \mathrm{~N}$.

\section{Pengemasan dalam bentuk biskuit}

Silase yang sudah selesai dibuat dikemas dalam bentuk biskuit. Pembuatan biskuit dilakukan dengan cara sebagai berikut: Masukkan silase dalam cetakan biskuit kemudian padatkan dan dilanjutkan dengan proses pemanasan

\section{HASIL DAN PEMBAHASAN}

Hasil Uji Organoleptik terhadap Pakan Hijauan yang dibuat dengan Teknik Silase
Hasil Pengujian organoleptik terhadap Pakan Hijauan yang dibuat dengan teknik silase dapat dilihat secara keseluruhan pada tabel 1 dibawah ini.

Dari Tabel 1 dapat diperoleh kesimpulan bahwa pakan hijauan yang dibuat dengan teknik silase rata-rata berkualitas baik.

\section{Hasil Analisa Proksimat Terhadap Pakan} Hijauan yang dibuat dengan Teknik Silase

Analisa Proximate hanya dapat dilakukan untuk penghitungan kadar berat kering. Pengujian Bahan organik dan penghitungan protein kasar belum dapat dilakukan karena terkendala dengan alat dan bahan kimia yang tersedia. Tabel 2 dibawah ini adalah hasil penghitungan berat kering $(\mathrm{BK})$ untuk pakan hijuan yang sudah dibuat dengan variasi waktu dan perlakuan serta pengulangan.

Berdasarkan Tabel 2 dapat dilihat bahwa kandungan Bahan kering tertinggi rata-rata berada pada perlakuan P0(kontrol).

Pakan Hijauan yang dibuat dengan teknik silase rata-rata berkualitas baik. Berkualitas sedang hanya ditemukan pada sampel jagung yang diberi perlakuan P3 (sampel + urea $\% \%+$ molases $10 \%+\mathrm{CaCO}_{3}$ $0,5 \%)$ untuk ketiga variasi waktu dan tiga kali pengulangan. Pakan hijaun berkualitas sedang ditandai dengan warna pakan yang sudah mendekati hijau pucat, bahkan beberapa nya mendekati warna hitam. Hal ini kemungkinan disebabkan oleh penambahan zat aditif yang berlebihan, sehingga kadar air meningkat. Meningkatnya kadar air mengakibatkan pertumbuhan jamur dan mikroorganisme menjadi tidak terkendali. Identifikasi pakan hijauan yang baik juga ditinjau dari bau pakan yang keasaman. Bau keasaman berasal dari produksi asam laktat sebagai hasil dari proses fermentasi karbohidrat. 
Sari., M. 2016. Pemanfaatan Limbah Jagung Untuk Pembuatan Biskuit Pakan Hijauan di Kecamatan Lima Kaum Batusangkar. Journal of Sainstek 8(2): 166-172

Tabel 1. Hasil Uji Organoleptik terhadap Pakan Hijauan

\begin{tabular}{|c|c|c|c|c|c|c|c|}
\hline \multirow[b]{2}{*}{ Variasi waktu } & \multirow[b]{2}{*}{ Perlakuan } & \multirow[b]{2}{*}{ Pengulangan } & \multirow[b]{2}{*}{ jamur } & \multicolumn{3}{|c|}{ Uji Organoleptik } & \multirow[t]{2}{*}{ kualitas } \\
\hline & & & & warna & aroma & lendir & \\
\hline \multirow[t]{12}{*}{$\mathrm{t} 1$} & P0 & 1 & ada & hijau & keasaman & sedikit & baik \\
\hline & & 2 & ada & hijau & keasaman & sedikit & baik \\
\hline & & 3 & ada & hijau & keasaman & sedikit & baik \\
\hline & $\mathrm{P} 1$ & 1 & ada & hijau & keasaman & sedikit & baik \\
\hline & & 2 & ada & hijau & keasaman & sedikit & baik \\
\hline & & 3 & ada & hijau & keasaman & sedikit & baik \\
\hline & $\mathrm{P} 2$ & 1 & ada & hijau pucat & keasaman & sedikit & sedang \\
\hline & & 2 & $\begin{array}{l}\text { tidak } \\
\text { ada }\end{array}$ & hijau & keasaman & sedikit & baik \\
\hline & & 3 & ada & hijau & keasaman & sedikit & baik \\
\hline & P3 & 1 & ada & $\begin{array}{l}\text { kuning } \\
\text { kehitaman }\end{array}$ & busuk & sedikit & buruk \\
\hline & & 2 & ada & hijau & busuk & sedikit & baik \\
\hline & & 3 & ada & hijau pucat & busuk & sedikit & sedang \\
\hline \multirow[t]{12}{*}{$\mathrm{t} 2$} & P0 & 1 & ada & hijau & keasaman & sedikit & baik \\
\hline & & 2 & ada & hijau & keasaman & sedikit & baik \\
\hline & & 3 & ada & hijau & keasaman & sedikit & baik \\
\hline & P1 & 1 & ada & hijau & keasaman & sedikit & baik \\
\hline & & 2 & ada & hijau pekat & keasaman & sedikit & sedang \\
\hline & & 3 & ada & hijau & keasaman & sedikit & baik \\
\hline & $\mathrm{P} 2$ & 1 & ada & hijau & keasaman & sedikit & baik \\
\hline & & 2 & ada & hijau & keasaman & sedikit & baik \\
\hline & & 3 & ada & hijau & keasaman & sedikit & baik \\
\hline & P3 & 1 & ada & $\begin{array}{l}\text { hijau } \\
\text { kehitaman }\end{array}$ & keasaman & banyak & sedang \\
\hline & & 2 & ada & hijau & keasaman & banyak & baik \\
\hline & & 3 & ada & hijau & keasaman & banyak & baik \\
\hline \multirow[t]{12}{*}{$\mathrm{t} 3$} & P0 & 1 & ada & hijau & keasaman & sedikit & baik \\
\hline & & 2 & ada & hijau & keasaman & sedikit & baik \\
\hline & & 3 & ada & hijau & keasaman & sedikit & baik \\
\hline & $\mathrm{P} 1$ & 1 & ada & hijau & keasaman & sedikit & baik \\
\hline & & 2 & ada & hijau & keasaman & sedikit & baik \\
\hline & & 3 & ada & hijau pucat & keasaman & sedikit & sedang \\
\hline & $\mathrm{P} 2$ & 1 & ada & hijau & keasaman & busuk & buruk \\
\hline & & 2 & ada & hijau & keasaman & sedikit & baik \\
\hline & & 3 & ada & $\begin{array}{l}\text { hijau } \\
\text { kehitaman }\end{array}$ & keasaman & busuk & buruk \\
\hline & P3 & 1 & ada & hijau & keasaman & sedikit & baik \\
\hline & & 2 & ada & hijau & keasaman & sedikit & baik \\
\hline & & 3 & ada & $\begin{array}{l}\text { hijau } \\
\text { kehitaman }\end{array}$ & keasaman & busuk & buruk \\
\hline
\end{tabular}


Sari., M. 2016. Pemanfaatan Limbah Jagung Untuk Pembuatan Biskuit Pakan Hijauan di Kecamatan Lima Kaum Batusangkar. Journal of Sainstek 8(2): 166-172

Tabel 2. Analisa Proksimat Terhadap Pakan Hijauan

\begin{tabular}{|c|c|c|c|c|c|c|c|c|}
\hline $\begin{array}{l}\text { Variasi } \\
\text { waktu }\end{array}$ & Perlakuan & $\mathrm{n}$ & $a(g)$ & $\mathrm{b}(\mathrm{g})$ & $c(g)$ & $\begin{array}{l}\text { kadar } \\
\text { air(g) }\end{array}$ & $\begin{array}{c}\text { berat } \\
\text { kering }(\mathrm{g})\end{array}$ & $\begin{array}{l}\text { rata- } \\
\text { rata }\end{array}$ \\
\hline \multirow[t]{12}{*}{$\mathrm{t} 1$} & P0 & 1 & 51,9 & 52,9 & 52,2 & 0,7 & 0,3 & 0,5 \\
\hline & & 2 & 55,7 & 56,7 & 56,6 & 0,1 & 0,9 & \\
\hline & & 3 & 60,2 & 52,9 & 52,2 & 0,7 & 0,3 & \\
\hline & $\mathrm{P} 1$ & 1 & 52 & 53 & 52,1 & 0,9 & 0,1 & 0,8 \\
\hline & & 2 & 55,7 & 56,7 & 56 & 0,7 & 0,3 & \\
\hline & & 3 & 21,6 & 22,6 & 21,9 & 0,7 & 0,3 & \\
\hline & $\mathrm{P} 2$ & 1 & 23,1 & 24,1 & 23,4 & 0,7 & 0,3 & 0,7 \\
\hline & & 2 & 63,3 & 64,3 & 63,5 & 0,8 & 0,2 & \\
\hline & & 3 & 51,6 & 52,6 & 51,9 & 0,7 & 0,3 & \\
\hline & $\mathrm{P} 3$ & 1 & 51,6 & 52,6 & 51,9 & 0,7 & 0,3 & 0,7 \\
\hline & & 2 & 63,2 & 64,2 & 63,6 & 0,6 & 0,3 & \\
\hline & & 3 & 55,7 & 56,7 & 56 & 0,7 & 0,3 & \\
\hline \multirow[t]{12}{*}{$\mathrm{t} 2$} & P0 & 1 & 23 & 24 & 23,3 & 0,7 & 0,3 & 0,7 \\
\hline & & 2 & 21,6 & 22,6 & 22 & 0,6 & 0,4 & \\
\hline & & 3 & 51,9 & 52,9 & 52,2 & 0,7 & 0,3 & \\
\hline & $\mathrm{P} 1$ & 1 & 51,6 & 52,6 & 51,9 & 0,7 & 0,3 & 0,6 \\
\hline & & 2 & 60,2 & 61,2 & 60,6 & 0,6 & 0,3 & \\
\hline & & 3 & 23,1 & 24,1 & 23,5 & 0,6 & 0,4 & \\
\hline & $\mathrm{P} 2$ & 1 & 55,7 & 56,6 & 56,1 & 0,5 & 0,3 & 0,6 \\
\hline & & 2 & 60,2 & 61,2 & 60,6 & 0,6 & 0,4 & \\
\hline & & 3 & 51,5 & 52,5 & 51,8 & 0,7 & 0,3 & \\
\hline & $\mathrm{P} 3$ & 1 & 51,5 & 52,5 & 51,9 & 0,6 & 0,4 & 0,6 \\
\hline & & 2 & 63,2 & 64,2 & 63,6 & 0,6 & 0,3 & \\
\hline & & 3 & 60,2 & 61,2 & 60,6 & 0,6 & 0,4 & \\
\hline \multirow[t]{12}{*}{$\mathrm{t} 3$} & P0 & 1 & 55,7 & 56,7 & 56,1 & 0,6 & 0,3 & 0,7 \\
\hline & & 2 & 63,3 & 64,3 & 63,4 & 0,9 & 0,1 & \\
\hline & & 3 & 51,5 & 52,5 & 51,9 & 0,6 & 0,3 & \\
\hline & $\mathrm{P} 1$ & 1 & 55,7 & 56,7 & 56,2 & 0,5 & 0,5 & 0,6 \\
\hline & & 2 & 60,3 & 61,3 & 60,6 & 0,7 & 0,3 & \\
\hline & & 3 & 63,3 & 64,3 & 63,6 & 0,7 & 0,3 & \\
\hline & $\mathrm{P} 2$ & 1 & 52 & 53 & 52,3 & 0,7 & 0,3 & 0,7 \\
\hline & & 2 & 21,6 & 22,6 & 21,8 & 0,8 & 0,2 & \\
\hline & & 3 & 51,9 & 52,9 & 52,4 & 0,5 & 0,3 & \\
\hline & P3 & 1 & 21,6 & 22,6 & 21,9 & 0,7 & 0,3 & 0,6 \\
\hline & & 2 & 23,1 & 24,1 & 23,6 & 0,5 & 0,3 & \\
\hline & & 3 & 51,9 & 52,9 & 52,4 & 0,5 & 0,5 & \\
\hline
\end{tabular}


Hasil Pengukuran bahan kering pada pakan hijauan yang dibuat dengan teknik silase dapat dilihat bahwa kandungan Bahan kering tertinggi rata-rata berada pada perlakuan P0(kontrol). Sesuai dengan pendapat Faharuddin, dkk bahwa tidak adanya penambahan zat aditif pada perlakuan akan mengakibatkan tidak terjadinya peningkatan kadar air dalam pakan hijauan. Penurunan Kadar berat kering ditunjukkan dengan adanya penambahan zat aditif dalam perlakuan. Pernyataan ini sependapat dengan Surono, dkk dalam Faharuddin bahwa terjadi peningkatan kehilangan bahan kering yang semakin besar seiring dengan meningkatnya level aditif. Semakin besar ketersediaan karbohidrat terlarut menyebabkan terjadinya peningkatan aktivitas fermentasi oleh bakteri untuk menghasilkan asam laktat sehingga menyebabkan kehilangan bahan kering yang lebih besar dalam ensilase tersebut. Menurut Sartini (2003) Penurunan bahan kering pada pakan hijauan dipengaruhi oleh respirasi dan fermentasi. Respirasi akan menyebabkan kandungan nutrien banyak yang terurai sehingga akan menurunkan bahan kering, sedangkan fermentasi akan menghasilkan asam laktat dan air.

Surono juga menyatakan menyatakan bahwa Peningkatan level aditif diduga memacu aktivitas fermentasi sehingga menyebabkan produksi air meningkat. Peningkatan kandungan air selama ensilase menyebabkan kandungan bahan kering menurun sehingga menyebabkan peningkatan kehilangan bahan kering. Semakin tinggi air yang dihasilkan selama ensilase, maka kehilangan bahan kering semakin meningkat. Oleh karena itu, peningkatan kehilangan bahan kering juga dipengaruhi oleh peningkatan kadar air yang berasal dari fermentasi gula sederhana.

Pada penelitian ini, bagian dari jagung yang diambil untuk sampel Pakan Hijauan adalah daun jagung. Menurut Yuli Retnani, dkk (2014) Dan jagung memiliki Palatabilitas yang baik sebagai pakan ternak sehingga sering digunakan sebagai pakan hijauan untuk pakan ruminansi.
Pakan Hijauan yang sudah dibuat dengan teknik silase dikemas menjadi biskuit. Biskuit pakan yang berbentuk padat, kompak, dan remah. Biskuit pakan yang berasal dari hijauan atau limbah pertanian merupakan salah satu solusi untuk menjawab harapan peternak. Biskuit pakan dibuat dari bahan yang mudah didapatkan dan diformulasikan dengan kandungan nutrisi sesuai dengan kebutuhan ternak.

\section{KESIMPULAN}

Jerami jagung sebagai limbah hasil pertanian ternyata dapat digunakan untuk membuat pakan hijauan yang dibuat dengan teknik silase. Pakan hijauan yang dibuat sudah memenuhi standar dari kementerian pertanian. Agar pakan menjadi lebih padat, pakan hijauan dicetak dalam bentuk biskuit yang padat, kompak dan remah dengan memanfaatkan panas dan tekanan.

\section{DAFTAR KEPUSTAKAAN}

AOAC. 1990. Association of Official Analytical Chemist. 15th Ed. Washington DC.

Bolsen KK \& DA Sapienza. 1983. Teknologi Silase diterjemahkan oleh B.S Martoyoedo. Pone. Foundation for Asia and The Pacific.

Dirjen Peternakan. 2005. Statistik Peternakan. Dirjen Peternakan Departemen Pertanian Republik Indonesia

Erpoman, $d k k$. 2011. Kajian Nutrisi dan Optimalisasi Proses Pengolahan Silase Jerami Jagung Muda sebagai Pakan Ternak Ruminansia. Artikel Penelitian Dosen Muda-Universitas Andalas.

Faharudin. 2014. Analisis Kandungan Bahan Kering, Bahan Organik, Protein Kasar Silase Pucuk Tebu yang di Fermentasi dengan Urea, Molases dan Kalsium Karbonat. Universitas Hasanudin.

Gaspersz V. 1991. Metode Perancangan Percobaan untuk Ilmu-ilmu Pertanian. Bandung: CV Armico. 
Hanafi ND. 2008. Teknologi Pengawetan Pakan Ternak. Universitas Sumatera Utara.

Mariyono dan E Romjali. 2007. Petunjuk Teknis Teknologi Inovasi 'Pakan Murah' Untuk Usaha Pembibitan Sapi Potong. Jakarta: Pusat Penelitian DanmPengembangan Peternakan Badan Penelitian Dan Pengembangan Pertanian Departemen Pertanian.

Mc Donalds P, RA Edward and JFD Greenhalgh. 1973. Animal Nutrition. $4^{\text {th }}$. ed. New York: LongmanScientific and Technology.

Mcllroy RJ. 1997. Pengantar Budidaya Potong Rumput Trapioka. Jakarta: Pradnya Paramita.
Retnani Y. 2015. Teknik Membuat Biskuit Pakan Ternak dari Limbah Pertanian. Penebar Swadaya.

Ridwan R, G Kartina dan Y Widyastuti. 2005. Pengaruh Penambahan Dedak dan Lactobacillus Plantarium dalam Pembuatan Silase Rumput Gajah. Media Peternakan.

Yuanita NL 2012. Urea Molases. http://nailyuthfiyasari Y.blog.ugm.ac.id.

Zakariah MA. 2012. Fermentasi Asam Laktat pada Silase. Fakultas Peternakan. Universitas Gajah Mada. Yogjakarta.

http://ntb.litbang.pertanian.go.id/ind/pu/psds/Pa kan.pdfhttp://pdf.usaid.gov/pdf_docs/PN AAR370.pdf

http://BPS.go.id 